\title{
Menthol decreases oral nicotine aversion in C57BL/6 mice through a TRPM8-dependent mechanism
}

\author{
Lu Fan, ${ }^{1}$ Shrilatha Balakrishna, ${ }^{1}$ Sairam V Jabba, ${ }^{2}$ Pamela E Bonner, ${ }^{2}$ Seth R Taylor, \\ Marina R Picciotto, ${ }^{1}$ Sven-Eric Jordt ${ }^{1,2}$
}

- Additional material is published online only. To view please visit the journal online (http://dx.doi.org/10.1136/ tobaccocontrol-2016-053209).

${ }^{1}$ Department of Psychiatry, Yale Tobacco Center of Regulatory Science (TCORS), Yale School of Medicine, New Haven, Connecticut, USA 2Department of Anesthesiology, Duke University School of Medicine, Durham, North Carolina, USA

\section{Correspondence to} Dr Sven-Eric Jordt, Department of Anesthesiology, Duke University School of Medicine, Box 3094 MS27, Durham, NC 27710-3094, USA; sven.jordt@duke.edu

Received 27 May 2016 Accepted 13 September 2016 Published Online First 3 October 2016

\section{CrossMark}

\section{To cite: Fan $\mathrm{L}$,}

Balakrishna S, Jabba SV

et al. Tob Control 2016;25: ii50-ii54.

\section{ABSTRACT}

Background Nicotine is a major oral irritant in smokeless tobacco products and has an aversive taste. Mentholated smokeless tobacco products are highly popular, suggesting that menthol increases their palatability and may facilitate initiation of product use. While menthol is known to reduce respiratory irritation by tobacco smoke irritants, it is not known whether this activity extends to oral nicotine and its aversive effects. Study design The two-bottle choice drinking assay was used to characterise aversion and preference in C57BL/6 mice to a range of menthol concentrations $(10-200 \mu \mathrm{g} / \mathrm{mL})$. Then, effects of menthol on oral nicotine aversion were determined. Responses were compared with those in mice deficient in the cold/ menthol receptor, TRPM8, expressed in trigeminal sensory neurons innervating the oral cavity.

Results Mice showed aversion to menthol concentrations of $100 \mu \mathrm{g} / \mathrm{mL}$ and above. When presented with a highly aversive concentration of nicotine $(200 \mu \mathrm{g} / \mathrm{mL})$, mice preferred solutions with 50 or $100 \mu \mathrm{g} / \mathrm{mL}$ menthol added over nicotine alone. In contrast to wild-type mice, Trpm8-/- showed a strong aversion to mentholated $(100 \mu \mathrm{g} / \mathrm{mL})$ nicotine $(200 \mu \mathrm{g} /$ $\mathrm{mL}$ ) and preferred nicotine alone. Trpm8-/- mice show aversion to lower concentrations of menthol than wildtype mice.

Conclusions Oral menthol can reduce the aversive effects of oral nicotine and, at higher concentrations, acts as an irritant by itself. Menthol's effects in relation to nicotine require TRPM8, the cool temperature sensing ion channel that activates analgesic and counterirritant mechanisms. These mechanisms may underlie preference for menthol-containing smokeless tobacco products and may facilitate initiation of product use.

\section{INTRODUCTION}

Smokeless tobacco products (snuff, chewing tobacco, snus and dissolvables) containing menthol are highly popular. ${ }^{1} 2$ Menthol adds a fresh, cooling and minty taste, sensations that are reminiscent of other tobacco products such as menthol cigarettes and of confectionary products such as chewing gum and mint lozenges. Menthol may increase the palatability of smokeless products that contain tobacco ingredients with aversive flavours, thereby facilitating initiation of product use. ${ }^{3}$

Nicotine levels in smokeless tobacco products are sufficient to be perceived as irritating by humans, eliciting burning and tingling sensations in the mouth. ${ }^{4} 5$ Nicotine also has an aversively bitter taste. ${ }^{5}$ In recent studies in mice, we demonstrated that menthol inhibits the respiratory irritation response to cigarette smoke irritants such as acrolein and to cigarette smoke itself. $^{6}{ }^{7}$ These mice had never been exposed to cigarette smoke before, mimicking initiating users. Higher levels of cotinine were detected in the mice inhaling mentholated cigarette smoke than in the mice inhaling non-mentholated smoke, implying that menthol increases nicotine uptake. ${ }^{7}$ These effects were observed at menthol levels present in smoke of commercial menthol cigarettes. ${ }^{7}$ Together these data suggested that menthol may facilitate smoking initiation by reducing aversion to noxious smoke. ${ }^{6-8}$

It is currently controversial whether menthol's counterirritant activity extends to oral nicotine and its aversive effects. Most studies examining the effects of menthol in the context of tobacco use were performed in chronic smokers and provide no information about menthol's behavioural effects during initiation of tobacco use. Menthol, at high levels, can also be perceived as irritating. ${ }^{4}$ A human psychophysical study demonstrated that menthol applied to the tongue at irritating concentrations caused desensitisation to nicotine later applied to the same location. ${ }^{4}$ Another human study using mentholated nicotine gums observed that menthol reduced pain and irritation elicited by nicotine, but only transiently, and some test participants perceived the high menthol concentrations in this study as irritating. ${ }^{5}$

Pain and irritation are initiated when noxious chemicals activate peripheral sensory nerves. ${ }^{9}$ Smoke irritants such as acrolein activate the sensory irritant receptor, TRPA1, in nerve endings in the mucosa of the throat and nasal passages. ${ }^{10}$ Oral nicotine activates nicotinic acetylcholine receptors (nAChRs) in sensory nerves innervating the tongue and oral cavity. ${ }^{11}{ }^{12}$ Nicotine also activates TRPA1, albeit higher concentrations are required than for nAChRs. ${ }^{13}$ The bitter taste associated with nicotine is likely mediated by bitter taste receptors in oral taste buds that signal to gustatory nerves. ${ }^{11} 14$

Menthol also has complex interactions with sensory nerves and their receptors. The cooling effect of menthol is mediated by the cold/menthol receptor, TRPM8, expressed in a subset of neurons sensitive to cool temperature. ${ }^{15} 16$ Activation of these neurons by menthol is thought to underlie menthol's analgesic and counterirritant effects. Indeed, menthol failed to inhibit smoke-induced respiratory irritation when mice were treated with a TRPM8 inhibitor before exposure. The irritant effects of menthol at higher concentration are likely mediated by TRPA $1 .{ }^{17} 18$

Mice are obligate nasal breathers, and access for inhaled air to the oral cavity is normally blocked. Thus, oral and respiratory sensing are separated, 
allowing selective study of oral effects. Here we used the twobottle choice paradigm in mice to investigate the effects of menthol on oral aversion to nicotine. The role of TRPM8 in these effects was investigated by comparing responses of wildtype mice with responses of TRPM8-deficient mice.

\section{METHODS}

\section{Animals}

Male C57/BL6 mice (adults aged 11 weeks) purchased from Charles River Laboratories were maintained in a AAALAC-certified facility in a temperature and humidity controlled room at a 12-hour light-dark cycle with unlimited access to food and water. Trpm8-/- mice were a gift from David Julius (University of California, San Francisco) and backcrossed into C57BL/6 background using marker-assisted backcrossing (Charles River Laboratories, Wilmington, Massachusetts, USA). All experimental protocols were approved by the Institutional Animal Care and Use Committees of Duke University and Yale University. No adverse events were noted during the course of the described experiments.

\section{Two-bottle choice assay}

Mice were housed individually in Med Associates behavioural chambers with water supply from drinking tubes manufactured from $25 \mathrm{~mL}$ serological pipette tubes with $0.2 \mathrm{~mL}$ graduations and stainless steel sipper tubes (Ancare, Part Number, OT99.5, with steel collars at a $90^{\circ}$ angle). Tubes were placed in each cage at an equal distance from food. Locations of the tubes were switched every 24 hours to control for side preferences. Each tube contained about $20 \mathrm{~mL}$ of liquid. The tubes were calibrated for fluid loss (leakage and evaporation) by placing them in empty cages for 4 days. Average fluid loss per 24 hours per two tubes was $0.4 \mathrm{~mL}$. Mice were acclimated to the two-tube system for 2-3 days with water only for 24 hours/day. To determine preference or aversion, choice solutions were provided overnight from 18:00 to 10:00. This period was chosen since mice are nocturnal, and the animal could remain close to their regular light-dark cycle. The rest of the day mice received tubes

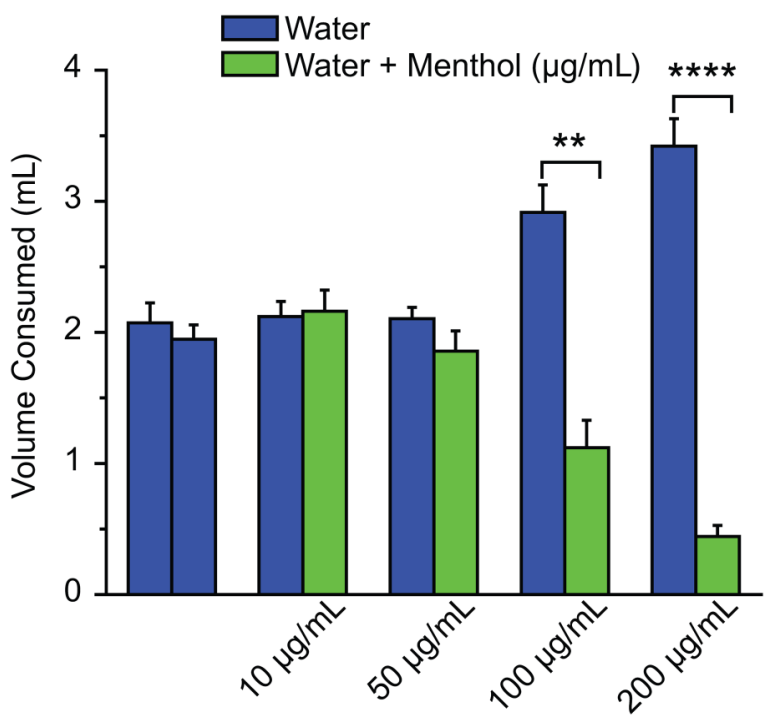

Figure 1 Effects of menthol on oral water consumption in mice in the two-bottle test. Consumption volumes of adult male C57BL/6 mice given the choice between water and menthol-containing water (1$100 \mu \mathrm{g} / \mathrm{mL}$ ), averaged over four nightly testing periods. Bars represent mean \pm SEM. ${ }^{* *} \mathrm{p}<0.01 ;{ }^{* * *} \mathrm{p}<0.0001 ; \mathrm{n}=5$ per group. filled with plain water and drank ad libitum. Control groups were provided with water only throughout the experiment. Liquid consumption from each tube was measured by comparing weights of the drinking tubes before and after the choice drinking periods. Investigators tasked with filling and swapping tubes were different from investigators reading fluid consumption. The latter were blinded to the tube contents.

\section{Menthol-flavoured solutions}

L(-) menthol was used in all studies, the minty and cooling menthol isomer added to tobacco products. ${ }^{19}$ Menthol solutions $(10-200 \mu \mathrm{g} / \mathrm{mL})$ were prepared by dissolving $\mathrm{L}(-)$-menthol (Acros Organics) in distilled deionised $\mathrm{H}_{2} \mathrm{O}\left(\mathrm{ddH}_{2} \mathrm{O}\right)$. Nicotine solutions $(200 \mu \mathrm{g} / \mathrm{mL})$ were prepared fresh daily by dissolving nicotine base (Sigma) in dd $\mathrm{H}_{2} \mathrm{O}$ or $10-200 \mu \mathrm{g} / \mathrm{mL}$ menthol solutions. Drinking tubes with nicotine solutions were protected from light by covering with aluminium foil.

\section{Statistical analysis}

For flavour preference study, data were averaged across the 4 days. One-way ANOVA was used to compare daily averaged liquid consumption among groups, and Tukey post hoc was used to compare between individual groups. In addition, a two-way ANOVA was performed to determine if daily liquid consumption differed from day to day within individual groups due to changes in tolerance over the period of experiment. Paired t-test was used to compare consumed liquid volume between the two choices within each group (" $p<0.05$; $*$ * $<0.01 ; * * \mathrm{p}<0.0005 ; * * * \mathrm{p}<0.0001)$

\section{RESULTS}

\section{Aversion to high concentrations of menthol in wild-type} C57BL/6 mice

Groups of male adult C57BL/6 mice were given the choice between water and water containing different concentrations of menthol (10-200 $\mathrm{g} / \mathrm{mL})$ overnight, with water ad libitum

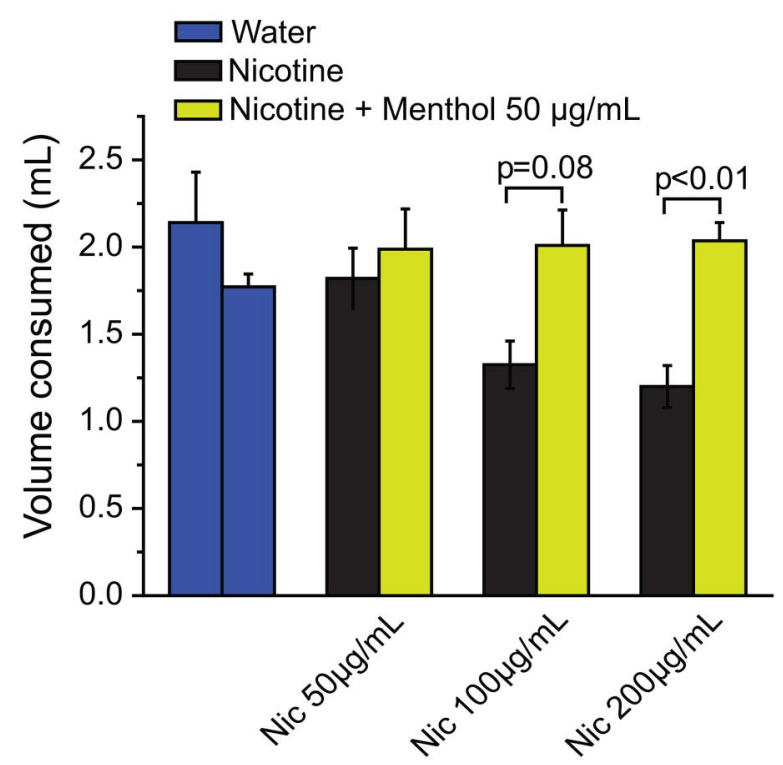

Figure 2 Effects of menthol on oral nicotine aversion in mice in the two-bottle test. Mice were given the choice between non-mentholated and mentholated $(50 \mu \mathrm{g} / \mathrm{mL})$ nicotine solutions, with nicotine contents of 50,100 or $200 \mu \mathrm{g} / \mathrm{mL}$. Water only served as control (blue). Bars show average consumption during four consecutive nightly choice periods. Error bars show SEM. $n=5-7$ for each group. 
during the day, for 4 days. At menthol concentrations exceeding $50 \mu \mathrm{g} / \mathrm{mL}$, the mice consumed less mentholated water and more plain water (figure 1).
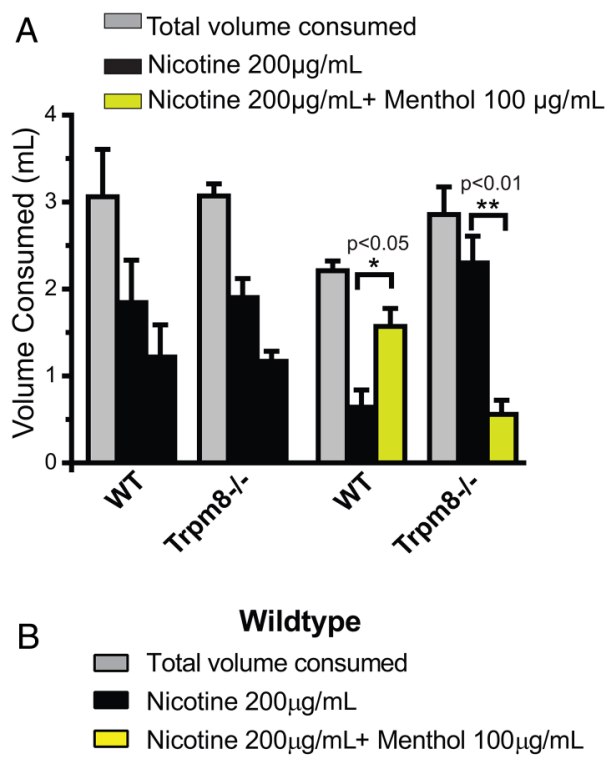

2-way ANOVA, ${ }^{* * *} p<0.0005$ for Nic. vs. Menth. Nic.

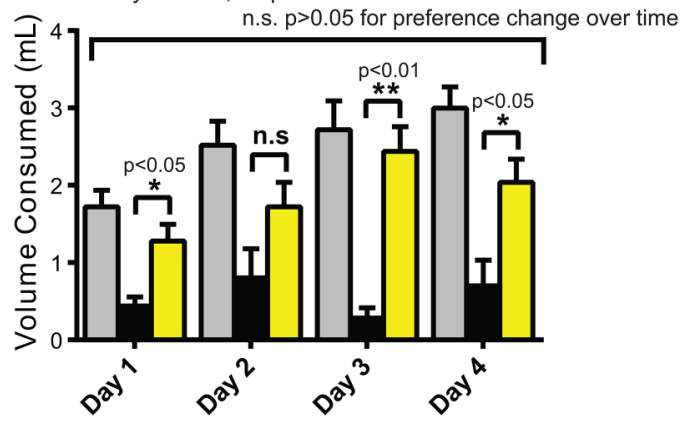

Trpm8-/-

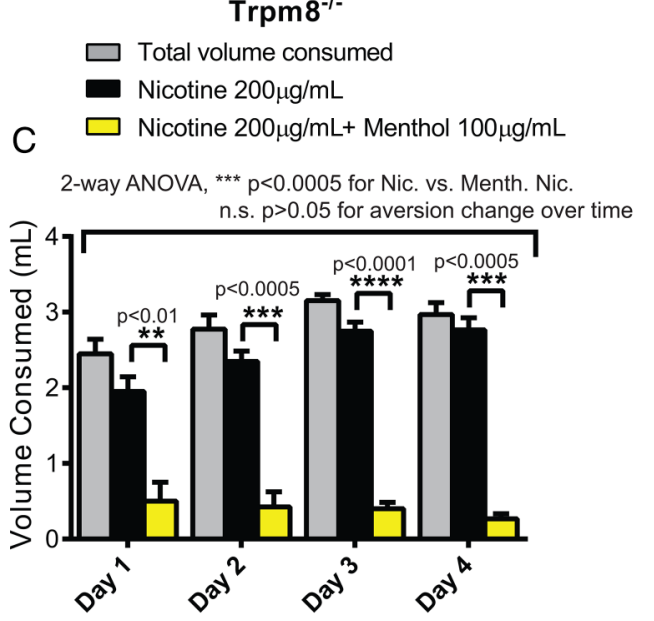

Figure 3 Consumption volumes of wild-type and Trpm8-/- mice in the two-bottle test with choice between nicotine only and mentholated nicotine. (A) Consumption volumes averaged over four nights of WT and Trpm8-I- mice. Mice were given choice of bottles filled with the same nicotine solution $(200 \mu \mathrm{g} / \mathrm{mL}$, black) or given the choice between nicotine $(200 \mu \mathrm{g} / \mathrm{mL}$, black) or nicotine $(200 \mathrm{mg} / \mathrm{mL})$ plus menthol $\left(100 \mu \mathrm{g} / \mathrm{mL}\right.$, yellow). Error bars represent SEM. ${ }^{*} \mathrm{p}<0.05 ;{ }^{*} \mathrm{k}<0.01$; $n=5-8$ for each group. Nightly consumption volumes during four nights of (B) the same WT mice and (C) the same Trpm8-/- mice. Two-way ANOVA analysis was performed to examine for potential tolerance. WT, wild-type.
Preference for mentholated nicotine solution in wild-type mice

The above studies demonstrate that menthol has aversive effects at higher concentrations. To examine the effects of menthol on nicotine consumption, we therefore chose non-aversive or weakly aversive concentrations of menthol $(50$ or $100 \mu \mathrm{g} / \mathrm{mL}$ ) and tested responses of mice given the choice between mentholated and non-mentholated nicotine solutions. A range of nicotine concentrations with known aversive effects was chosen (50, 100 and $200 \mu \mathrm{g} / \mathrm{mL})^{20}$ When offered $200 \mu \mathrm{g} / \mathrm{mL}$ nicotine, mice clearly preferred the mentholated $(50 \mu \mathrm{g} / \mathrm{mL})$ nicotine solution over nicotine alone (figure 2).

\section{Aversion to mentholated nicotine solution in TRPM8-deficient mice}

Wild-type mice also preferred nicotine solution $(200 \mu \mathrm{g} / \mathrm{mL})$ containing $100 \mu \mathrm{g} / \mathrm{mL}$ menthol (figure 3A). When mice deficient in the cold/menthol receptor, TRPM8, were given the same choice, the preference was reversed (figure 3A). Trpm8-/mice clearly preferred the non-mentholated nicotine solution and avoided the mentholated solution. Preference for mentholated nicotine solution was evident on each of the 4 days of testing in wild-type mice (figure 3B). Trpm8-/- mice, however, preferred non-mentholated nicotine solution on all 4 days (figure 3C). Also, a two-way ANOVA was performed to determine if daily consumption of nicotine only solution versus mentholated nicotine differed from day to day within individual groups due to potential development of tolerance over the experimental period. Neither in wild-type nor in Trpm8-/mice there was a change in tolerance for the solution they showed aversion against.

\section{Stronger aversion to menthol in Trpm8-/- mice}

Intrigued by the observation of strong aversion to mentholated nicotine solution in Trpm8-/- mice we examined whether aversion to menthol or nicotine alone differs between wild-type and Trpm8-/- mice. The dose-response relationship for menthol aversion showed a clear shift to lower menthol concentrations in Trpm8-/- mice, with a $50 \mu \mathrm{g} / \mathrm{mL}$ solution clearly producing aversion (figure 4A, B). Wild-type and $\operatorname{Trpm} 8-/-$ mice displayed robust aversion to nicotine at 100 and $200 \mu \mathrm{g} / \mathrm{mL}$ (figure 4C, D).

\section{DISCUSSION}

The present study clearly demonstrates that menthol can diminish the oral aversion of mice to nicotine. Mice display aversion to higher menthol concentrations, but non-aversive or mildly aversive concentrations of menthol do not produce more aversion when combined with nicotine. Instead, mentholated nicotine solutions are favoured.

The oral menthol and nicotine concentrations producing behavioural effects in our study fall within the range of concentrations estimated to be present in the oral cavity of smokeless tobacco product users. Pouches of snus or moist snuff contain between 3.09 and $5.25 \mathrm{mg} / \mathrm{g}$ menthol. ${ }^{21}$ Menthol-flavoured snus pouches weighed between 531 and $970 \mathrm{mg}^{22}$ Accordingly, the content of menthol per pouch is within a range of $1.64-5.09 \mathrm{mg}$ (see online supplementary table 1 ). In a healthy human, averaged stimulated saliva flow is $1-2 \mathrm{~mL} / \mathrm{min}^{23}$ Assuming a pouch is used for $20 \mathrm{~min}, 20-40 \mathrm{~mL}$ of saliva are produced within this time. Supposing that all menthol is released from the pouch, the resulting average menthol concentrations in saliva would be between 0.041 and $0.082 \mathrm{mg} / \mathrm{mL} \quad(262-524 \mu \mathrm{M})$ when small pouches with lower menthol contents are used and 

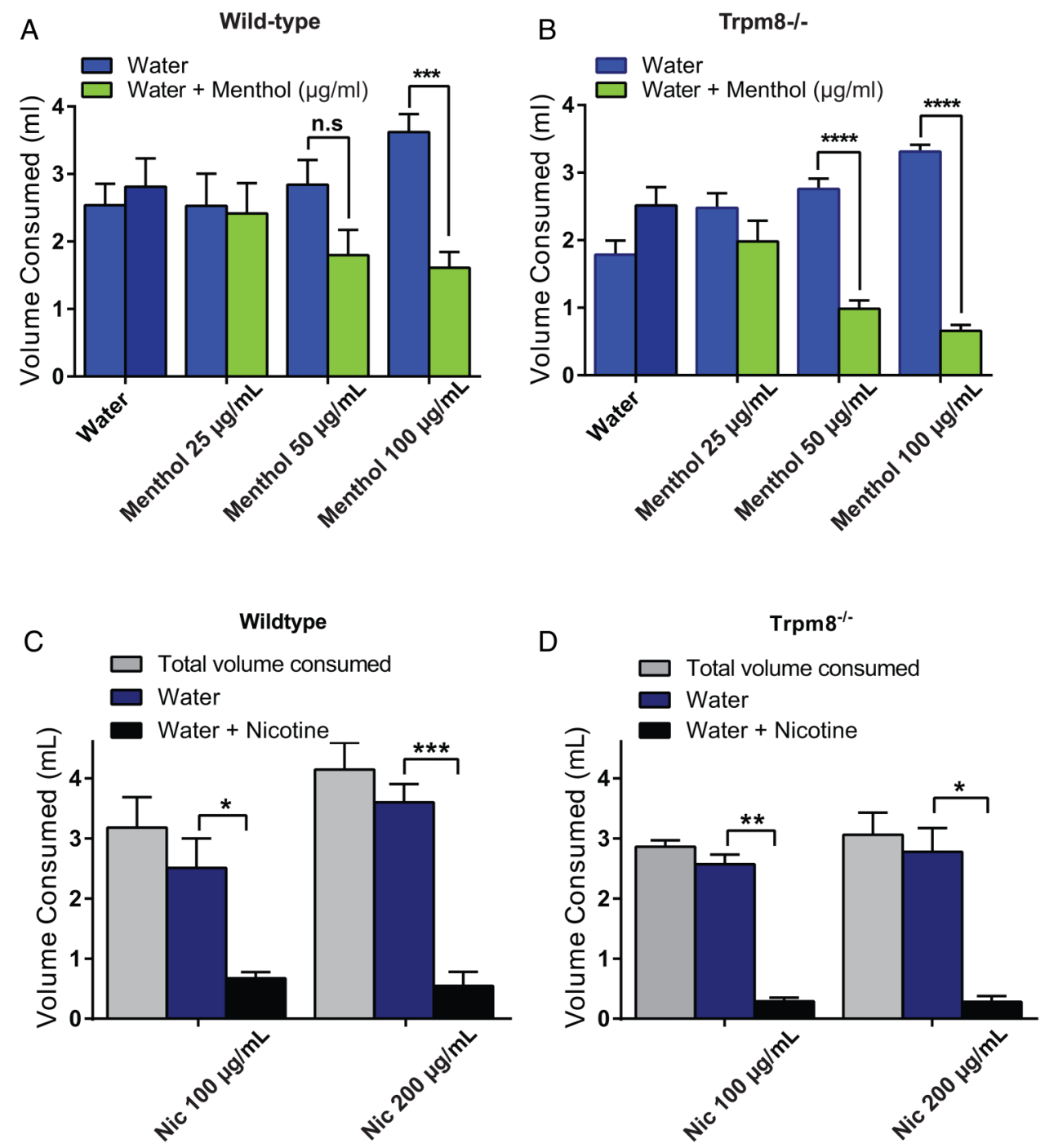

Figure 4 Comparison of menthol and nicotine sensitivity of wild-type and Trpm8-/- mice in the two-bottle test. (A) Consumption volumes averaged over four nights of wild-type mice given the choice of water only (blue) or water plus menthol (25, 50 and $100 \mu \mathrm{g} / \mathrm{mL}$, green). Error bars represent SEM. ${ }^{* * *} p<0.001 ; n=3$ per group. (B) Consumption volumes averaged over four nights of Trpm8-/- mice given the choice of water only (blue) or water plus menthol $\left(25,50\right.$ and $100 \mu \mathrm{g} / \mathrm{mL}$, green). Error bars represent SEM. ${ }^{* * * *} \mathrm{p}<0.0001 ; \mathrm{n}=4$ per group. (C) Consumption volumes averaged over four nights of wild-type mice given the choice of water only (blue) or water plus nicotine (100 or $200 \mu \mathrm{g} / \mathrm{mL}$, black). $\mathrm{n}=5 \mathrm{per}$ group. (D) Consumption volumes averaged over four nights of Trpm8-/- mice given the choice of water only (blue) or water plus nicotine $(100$ or $200 \mu \mathrm{g} / \mathrm{mL}$, black). $n=4$ per group.

$0.07-0.14 \mathrm{mg} / \mathrm{mL}(445-890 \mu \mathrm{M})$ for pouches with higher menthol contents (see online supplementary table 1). Similarly, menthol concentration in the saliva would be $0.075-0.15 \mathrm{mg} /$ $\mathrm{mL}$ (477-954 $\mu \mathrm{M}$ ) for larger pouches with lower menthol contents and $0.13-0.26 \mathrm{mg} / \mathrm{mL}(827 \mu \mathrm{M}-1.66 \mathrm{mM})$ for higher menthol-containing pouches (see online supplementary table 1). All these concentrations are sufficient to stimulate, and potentially saturate, TRPM8 and TRPA1 activity. The menthol concentrations diminishing nicotine aversion in mice in the present study, $50 \mu \mathrm{g} / \mathrm{mL}=320 \mu \mathrm{M}$ and $100 \mu \mathrm{g} / \mathrm{mL}=640 \mu \mathrm{M}$, are within the range of the estimated saliva concentrations and will strongly activate TRPM8 and TRPA1.

Nicotine contents vary between 2 and $10 \mathrm{mg}$ per pouch, depending on product. ${ }^{22}$ If released completely, average concentrations in saliva would exceed $50 \mu \mathrm{g} / \mathrm{mL}$, potentially reaching $500 \mu \mathrm{g} / \mathrm{mL}$. The nicotine concentrations used here were 50$200 \mu \mathrm{g} / \mathrm{mL}(0.3-1.23 \mathrm{mM})$, well within this range. At these concentrations, peripheral nicotine activates nAChRs in nociceptor sensory neurons innervating the oral cavity. Nicotine may also activate TRPA1 at these concentrations, however, reported dose-response data are inconsistent and depend on the experimental model or preparation. ${ }^{13}$ Activation of these targets will elicit irritation and pain and contribute to oral nicotine aversion. Nicotine also tastes bitter, a sensation mediated by bitter taste receptors expressed in the taste buds of the tongue.

In the current study, TRPM8, the cold/menthol receptor, was proven to be essential for menthol's effects on oral nicotine aversion. In contrast to wild-type mice in which menthol diminished nicotine aversion, the same combination of menthol $(100 \mu \mathrm{g} / \mathrm{mL})$ with nicotine $(200 \mu \mathrm{g} / \mathrm{mL})$ was avoided by TRPM8-deficient mice that strongly favoured plain nicotine solution. It is likely that TRPM8-expressing trigeminal sensory neurons innervating the oral cavity and tongue activate inhibitory circuits in the trigeminal nucleus that dampen input from nicotine-activated nociceptors, thereby diminishing oral irritation and pain. Menthol is also an irritant, activating irritant receptor TRPA1 in nociceptors. It is likely that menthol-activated TRPM8-expressing neurons also dampen menthol's irritant 
effects, similar to its effect on nicotine. In TRPM8-deficient mice, this diminishing effect is gone; menthol's irritancy is unmasked and adds to the irritancy of nicotine instead. This effect likely explains why Trpm8-/- mice avoided mentholated nicotine solution and preferred plain nicotine solution.

The present study demonstrates that menthol, at concentrations similar to those estimated for saliva of smokeless tobacco product users, has strong receptor-mediated pharmacological effects on the observed behavioural aversion to nicotine. The mice used in our study had not been exposed to nicotine before, resembling initiating smokeless tobacco product users. Menthol's effect on nicotine aversion did not change over the 4 days of our experiment, suggesting that menthol's effects do not desensitise in the first days of the initiation period.

Humans and rodents express TRPM8 ion channels in the trigeminal neurons innervating the oral cavity. The amino acid sequences of human and mouse TRPM 8 are $94 \%$ identical (NCBI Blast algorithm), with identity especially high within the transmembrane moiety binding to menthol and conducting ions. This degree of identity is in the same range, or higher, than for most human and mouse nAChRs ( $\alpha 2$ : $85 \%$ identical, B4: $94 \%$ identical). This high degree of species similarity extends to the dose-response relationship with menthol that are also almost identical, with $\mathrm{EC}_{50} \mathrm{~s}$ for human TRPM8 $=3.7$ $\pm 0.1 \mu \mathrm{M}$ and for mouse TRPM8 $=4.1 \pm 1.3 \mu \mathrm{M} .{ }^{24}{ }^{25}$ On the basis of these similarities, it can be assumed that menthol has similar effects in humans, diminishing nicotine's irritant effects in the oral cavity at the menthol concentration used here. ${ }^{24}$ This effect may facilitate initiation of smokeless tobacco product use and increase the population of users developing and maintaining nicotine addiction.

\section{What this paper adds}

- Menthol is a popular flavour among users of oral smokeless tobacco products such as snuff and snus. It remains unclear whether oral menthol masks the aversive sensory effects of nicotine and other tobacco constituents and thereby facilitates initiation.

- This paper demonstrates that menthol reduces oral aversion to nicotine in mice, in the concentration range released by smokeless tobacco products.

- The oral counterirritant effects of menthol are absent in mice deficient in TRPM8, the cold/menthol receptor expressed in sensory nerves, demonstrating that menthol has pharmacologically potent and receptor-mediated effects.

- Regulation of menthol levels in smokeless product may be a means to modulate smokeless product use initiation and preferences.

Correction notice This article has been corrected since it was published Online First. In the Abstract, ' $50 \%$ or $100 \mathrm{mg} / \mathrm{mL}$ ' has been corrected to '50 or $100 \mathrm{mg} /$ $\mathrm{mL}^{\prime}$ in the sentence 'When presented with a highly aversive concentration of nicotine $(200 \mathrm{mg} / \mathrm{mL})$, mice preferred solutions with 50 or $100 \mathrm{mg} / \mathrm{mL}$ menthol added...'

Contributors S-EJ and MRP conceived of the study. LF, SB, SVJ, PEB and SRT performed experiments. LF, SB, SVJ, MRP and S-EJ contributed to data analysis; interpretation of data; writing of the manuscript and review, revision and approval of the final article. S-EJ is guarantor of the study.

Funding This work was supported by the National Institute on Drug Abuse and the Center for Tobacco Products of the US Food and Drug Administration under Award Numbers P50DA036151 (Yale Tobacco Center of Regulatory Science, TCORS).
Disclaimer The content is solely the responsibility of the authors and does not necessarily represent the views of the NIH or the FDA.

Competing interests None declared.

Provenance and peer review Not commissioned; externally peer reviewed.

Data sharing statement Data are available for download on request from the Duke Department of Anesthesiology's primary data server.

\section{REFERENCES}

1 Alpert HR, Koh H, Connolly GN. Free nicotine content and strategic marketing of moist snuff tobacco products in the United States: 2000-2006. Tob Control 2008; 17:332-8

2 Villanti AC, Richardson A, Vallone DM, et al. Flavored tobacco product use among US young adults. Am J Prev Med 2013;44:388-91.

3 TPSAC. Menthol cigarettes and public health: review of the scientific evidence and recommendations. Center for Tobacco Products, Food and Drug Administration (FDA). 2011. http://www.fda.gov/downloads/AdvisoryCommittees/Committees MeetingMaterials/TobaccoProductsScientificAdvisoryCommittee/UCM247689.pdf

4 Dessirier JM, O'Mahony M, Carstens E. Oral irritant properties of menthol: sensitizing and desensitizing effects of repeated application and cross-desensitization to nicotine. Physiol Behav 2001;73:25-36.

5 Arendt Nielsen T, Nielsen BP, Wang K, et al. Psychophysical and vasomotor responses of the oral tissues: a nicotine dose-response and menthol interaction study. Nicotine Tob Res 2016;18:596-603.

6 Willis DN, Liu B, Ha MA, et al. Menthol attenuates respiratory irritation responses to multiple cigarette smoke irritants. FASEB J 2011:25:4434-44.

7 Ha MA, Smith GJ, Cichocki JA, et al. Menthol attenuates respiratory irritation and elevates blood cotinine in cigarette smoke exposed mice. PLoS One 2015;10: e0117128

8 Delnevo CD, Villanti AC, Wackowski OA, et al. The influence of menthol, e-cigarettes and other tobacco products on young adults' self-reported changes in past year smoking. Tob Control 2016;25:571-4

9 Basbaum Al, Bautista DM, Scherrer G, et al. Cellular and molecular mechanisms of pain. Cell 2009;139:267-84.

10 Bautista DM, Jordt SE, Nikai T, et al. TRPA1 mediates the inflammatory actions of environmental irritants and proalgesic agents. Cell 2006;124:1269-82.

11 Gyekis JP, Dingman MA, Revitsky AR, et al. Gustatory, trigeminal, and olfactory aspects of nicotine intake in three mouse strains. Behav Genet 2012;42: 820-9.

12 Carstens E, Simons CT, Dessirier JM, et al. Role of neuronal nicotinic-acetylcholine receptors in the activation of neurons in trigeminal subnucleus caudalis by nicotine delivered to the oral mucosa. Exp Brain Res 2000;132:375-83.

13 Kichko TI, Lennerz J, Eberhardt M, et al. Bimodal concentration-response of nicotine involves the nicotinic acetylcholine receptor, transient receptor potential vanilloid type 1, and transient receptor potential ankyrin 1 channels in mouse trachea and sensory neurons. J Pharmacol Exp Ther 2013;347:529-39.

14 Ahijevych K, Tepper BJ, Graham MC, et al. Relationships of PROP taste phenotype, taste receptor genotype, and oral nicotine replacement use. Nicotine Tob Res 2015; 17:1149-55.

15 Jordt SE, McKemy DD, Julius D. Lessons from peppers and peppermint: the molecular logic of thermosensation. Curr Opin Neurobiol 2003;13:487-92.

16 McKemy DD, Neuhausser WM, Julius D. Identification of a cold receptor reveals a general role for TRP channels in thermosensation. Nature 2002:416:52-8.

17 Karashima Y, Damann N, Prenen J, et al. Bimodal action of menthol on the transient receptor potential channel TRPA1. J Neurosci 2007;27:9874-84.

18 Liu B, Fan L, Balakrishna S, et al. TRPM8 is the principal mediator of mentholinduced analgesia of acute and inflammatory pain. Pain 2013:154:2169-77.

19 Chen C, Luo W, Isabelle LM, et al. The stereoisomers of menthol in selected tobacco products. A brief report. Nicotine Tob Res 2011;13:741-5.

20 Robinson SF, Marks MJ, Collins AC. Inbred mouse strains vary in oral self-selection of nicotine. Psychopharmacology (Berl) 1996;124:332-9.

21 Chen C, Isabelle LM, Pickworth WB, et al. Levels of mint and wintergreen flavorants: smokeless tobacco products vs. confectionery products. Food Chem Toxicol 2010;48:755-63.

22 Stepanov I, Jensen J, Biener L, et al. Increased pouch sizes and resulting changes in the amounts of nicotine and tobacco-specific $N$-nitrosamines in single pouches of Camel Snus and Marlboro Snus. Nicotine Tob Res 2012;14:1241-5.

23 Navazesh M, Christensen C, Brightman V. Clinical criteria for the diagnosis of salivary gland hypofunction. J Dent Res 1992;71:1363-9.

24 Behrendt HJ, Germann T, Gillen C, et al. Characterization of the mouse cold-menthol receptor TRPM8 and vanilloid receptor type-1 VR1 using a fluorometric imaging plate reader (FLIPR) assay. Br J Pharmacol 2004;141:737-45.

25 Klein AH, lodi Carstens M, McCluskey TS, et al. Novel menthol-derived cooling compounds activate primary and second-order trigeminal sensory neurons and modulate lingual thermosensitivity. Chem Senses 2011;36:649-58. 